\title{
Good Faith in Life Insurance Contract by Indonesian Court
}

\author{
Mokhamad Khoirul Huda \\ Faculty of Law, Hang Tuah University \\ Jln. Arif Rahman Hakim No. 150 Surabaya 60111, Indonesia. \\ Tel./Fax: +62-31-5946261E-mail: emka.huda@hangtuah.ac.id
}

Submitted: Mar 3, 2017; Reviewed: Mar 22, 2017; Accepted: Mar 27, 2017

\begin{abstract}
This paper reviews both the interpretation of good faith and its implementation by the Court in terms of life insurance contracts. The principle of good faith in life insurance contracts was under the provision of the Article 251 Wet Boek van Kophandel which assigned the obligation of good faith on the insured. Based on the context of its historical and systematical interpretation, the obligation of good faith should be on both sides, the insurer and the insured. The insured had an obligation to inform any material facts and the insurer had to investigate those all facts. Until recent days, however, judges in all levels of Court did not have any shared and full understanding on the interpretation of good faith in life insurance contracts. As the result, many Courts were frequently inconsistent with each other. Hence, the sense of fairness the people perceived from the court verdict was not achieved.
\end{abstract}

Keywords: Contract; Court; Good Faith; Material Fact; The Insured; The Insurer

DOI: 10.20956/halrev.v3i1.1046

\section{INTRODUCTION}

The Indonesian Central Statistics (Badan Pusat Satitistik - The BPS) showed the number of Indonesia population in 2000 was $205,132,458.00$ people with the growth rate in $1.4 \%$ between periods of year 1990 2000. Subsequently, based on the census in 2010, it reached 237.556.363.00 people with the growth rate in $1.49 \%$ between period of year 2000-2010. ${ }^{1}$ In 2013, National Family Planning Coordinating Agency estimated that the population of Indonesia had reached

\footnotetext{
Badan Pusat Statistik. (2011). Statistik Indonesia (Statistical Yearsbook of Indonesia 2011). Jakarta: BPS, p. 47.
}

250 people. ${ }^{2}$ Approximately 43.7 million people or $18 \%$ of the total population had life insurance. From the total population who joined insurance in 2012, Indonesian Life Insurance Association successfully collected Rp 1,946 trillion or increased up to $17.6 \%$ compared with fund collection in 2011, which was Rp 1,656 trillion. The increasing number of the insured indicated an increasing public awareness on the importance of life insurance. ${ }^{3}$

2 Badan Pusat Statistik.(2015) Statistik Indonesia (Statistical Yearsbook of Indonesia 2015). Jakarta: BPS, p. 76.

3 Anonymous. "Dana Pertanggungan Asuransi Jiwa Capai Rp.1.946 Triliun." Available online at: http:// 
The increasing number of the insured affected insurance claiming disputes. Indonesian Insurance Mediation Board not$\mathrm{ed}^{4}$ that there had been 138 cases or leapt to $158 \%$ compared with the cases in 2011 which was only 48 cases. Until recent days, it was 93 cases which sued that the insurer had to pay the claim. By 2013, the total cases of claiming disputes was 41 cases comprising 27 cases on life insurance and 14 cases on general insurance.

Life insurance disputes happened since the insured was considered to have no act of good faith in filling Life Insurance Proposal Form by not providing any correct information (misrepresentation) or by not informing material facts they actually knew (nondisclosure). ${ }^{5}$ In addition, all institutions of modern society, such as the market, state authorities, associations of persons, etc. pose certain demands and expectations on private relations, which depend on a vast range of different social factors. ${ }^{6}$ This also causes the instability of the principle of good faith and a constant development of its content.

Good faith in life insurance contract required the insured to thoroughly and clearly inform all the material facts related to the insured object. ${ }^{7}$ All the insurer needed was that he insured had to clearly and completely provide any information dealing with the

www.e-Money News.htm, [Acessed May 1, 2015].

4 BMAI."Rekapitulasi Jumlah Sengketa." Available online at: http://www.bmai.or.id/ [Accessed on 18 April 2014].

5 Mokhamad Khoirul Huda. (2016). Prinsip Iktikad Baik dalam Perjanjian Asuransi Jiwa. Yogyakarta: UII Press, p. 7.

6 Irene Kull. (2002). "Principle of Good Faith and Constitutional Values in Contract Law". Juridica International, VII: 142-148.

7 Robert Merkin. (2007). Practical Insurance Guides: Insurance Law-An Introduction. London: Informa, p. 37. possible risks assigned to the insurer. ${ }^{8}$ The insured provided information through which the insurer could see the weight of risk they would take over. Thus, the insurer absolutely needed to clearly know about the object of insurance contract. ${ }^{9}$

The insurer used the reason telling that the insured had no good faith to provide correct information's of material facts they should know in order to terminate the contract (e.g., the insured did not honestly tell about his/her medical condition). ${ }^{10}$ This was the beginning of life insurance disputes to be resolved in court.

Judges, in making particular verdict, had different exegesis in terms of their interpretation of good faith. Hence, they had to be up-to-date with current development and renewed the provision of Law. Relating to this matter, Cardozo ${ }^{11}$ stated as follows:

"My duty as judge may be objectify in law, not my own aspiration and conviction and philosophies, but the aspiration and conviction and philosophizer of the men and women on my time. Hardly shall I do this well if may own sympathies and beliefs and passionate devotions are with a time that is past."

A good judge is a translator of justice. Judges should follow and fully comprehended on the changing value in societal relationships. Hence, a justice could not exist or be born from a mere theory, because justice

8 Viktor Dover. (1975). A Handbook to Marine Insurance. $8^{\text {th }}$ edition. London: Withherby \& Co.Ltd, p. 343.

9 H.M.N. Purwosutjipto. (1990). Pengertian Pokok Hukum Dagang Indonesia: Hukum Pertanggungan. Jakarta: Djambatan, p. 52.

10 Santoso Poedjosoebroto. (1969). Beberapa Aspek tentang Hukum Pertanggungan Jiwa di Indonesia. Jakarta: Bhratara, p. 138.

11 Benjamin N. Cordozo. (2009). The Nature of The Judicial Process. New York: Cosimo. Inc, pp. 20-25. 
is naturally born from the deepest conscience of a judge who is also a human being. ${ }^{12}$ With a good interpretation, law would be long live over generations by providing justice for people, since every single person would always desire on justice in protecting their rights and obligations in life.

\section{ANALYSIS AND DISCUSSION}

\section{Good Faith in Life Insurance Contract}

The general system for the principle of good faith had been set under the Article 1338 act (3) Burgelijke wet Boek, and specifically set insurance contract based on the Article Wet Boek van Kophandel which mentioned that:

"Every incorrect or wrong information, or every matters that the insured did not tell, whatever the good fate embedded within, with that condition, therefore, if the insured had already knew the true condition, the contract would or would not end by similar condition, resulting in an termination of the insurance." 13

The Article 251 Wet Boek van Kophandel recognized pre-contract good faith with subjective standard. Pre-contract good faith was an obligation to inform or clarify (mededelingsplicht) and investigate (onderzoekplicht) material facts for related parties dealing with negotiated subjects. Subjective standard, however, related to inner-attitude and the psychology of both parties in making a life insurance contract. ${ }^{14}$

The principle contained in the Article 251 Wet Boek van Kophandel was uberrima

12 Harifin A. Tumpa. (2015). "Penerapan Konsep Rechtsvinding dan Rechtsschepping oleh Hakim dalam Memutus Suatu Perkara". Hasanuddin Law Review, 1(2), 126-138. doi: http://dx.doi.org/10.20956/halrev. $\mathrm{v} 1 \mathrm{ln} 2.90$

13 Subekti and Tjitrosudibio, Op.Cit., pp. 74-75.

14 Mokhamad Khoirul Huda, Op.Cit., pp. 258-259 fides or uberrima fidae. ${ }^{15}$ Those terms derived from Latin referring to: "a phrase used to express the perfect good faith, concealing nothing, with which a contract must be made; for example, in the case of insurance, the insured must observe the most perfect good faith towards the insurer"'16

Uli Foerstl ${ }^{17}$ argued that the word fides derived from "the name of the Roman goddess fides, the deification of good faith and honesty, the oath, and that one must keep one's word." The main concept of bona fides was fides. This Fides was developed as the standard of contract procedures, known as exceptio doli. The principle of good faith, then, evolve in Dutch, called "te goede trouw" and in Britain, called "good faith." 18

Pre-contract good faith in life insurance was set under the provision of the Article 7.17.1.928 act (1) Niuwe Bergerlijke wet Boek which mentioned as follows:

"Prior to concluding the contract the policyholder must disclose to the insurer all facts of which he is or ought to be aware and on which, as he knows or ought to understand, the decision of the insurer whether, and if so, on what terms, the latter is willing to conclude the insurance will or may depend".

The interpretation of pre-contract good faith was in Dutch jurisprundence in

15 Ridwan Khairandy. (2004). Iktikad Baik dalam Kebebasan Berkontrak. Jakarta: Universitas Indonesia, p. 13.

16 Douglas F. Robinson Q.C. and John Neocleous. (1998). "Issues of Insurance Fraud". International Symposium on The Prevention \& Control of Financial Fraud, Beijing, 19-22, October 1998, p. 11.

17 Uli Foerstl, Op.Cit., p. ii.

18 Carlo van Eijken, Bestaan er Verschillen Tussen het Nederlandse en het Engelse Recht als het Gaat om de Goede Trouw Tijdens de Onderhandelingen bij Bedrijfsovernames?, Scriptie Geschreven ter Afronding van de Master Privaatrechtelijke Rechtspraktijk aan de Universiteit van Amsterdam, p. 6. 
Baris v. Riezenkamp case, Hoge Raad on $15^{\text {th }}$ November 1957, NJ 1958, 67. Hoge Raad verdict stated that negotiating parties should be based on good faith. Thus, one party should consider the legal interests of another party in a contract. Hoge Raad, then, formulated or took the principle of accuracy in establishing contracts (contractuele zorgvuldigheid, duty of care), that is, accuracy for buyer to investigate or inspect (onderzoeksplicht) material facts related to the contract subject. ${ }^{19}$

A case between D. Tilkemena $v$. De Bataafsche Verzekering Maatschappij N.V., on $8^{\text {th }}$ June 1962 NJ. 1962, 366. ${ }^{20}$ Tilkemena had took an insurance from De Bataafsche Verzekeringmaatschppij N.V. When asking for insurance to be covered, he did not inform that he had frequently been in jail for many Civil crimes he did years ago. However, since he was never asked about his profile, it could not be considered that the insured should have known that such untold information was actually important for the insurer. Hoge Raad, then, interpreted the Article 251 Wet Boek van Kophandel by saying that the contract was terminated on behalf of law if the insured deliberately hide the information (verzwijging). The contract could only be terminated by judges at the insurer's request if the insured provided incorrect or wrong information (verkeerde of ontwaarachtige opgave). Disclosure obligation for Arrest Tilkemena in NBW had been set under the Article 7.17.1.928 act (1) and act (6). ${ }^{21}$

\footnotetext{
19 Ridwan Khairandy, Op.Cit., p. 14.

20 Man Suparman and Endang.(2004). Hukum Asuransi: Perlindungan Tertanggung, Asuransi Deposito, Usaha Perasuransian. $3^{\text {rd }}$ edition. Bandung: Alumni, p. 33.

${ }^{21}$ M. Keijzer de Korver. (2008). Verzekering en aan
}

Arrest Hoge Raad on $19^{\text {th }}$ Mei 1978 NJ.607 ${ }^{22}$ was about a case between $\mathrm{X}$ in Belgium and De naamloze vennootschaap Goudse Verzekering Maatschappij N.V in Amsterdam. Whether or not the importance of information provided by the insured as being set under the Article 251 Wet Boek van Kophandel should be measured based on a prudent insure, indicating that the insurer did seek out the importance of intended information. In this case, the insured had to be honest in informing anything he/she knew dealing with the insured object.

The enactment of the Article 251 Wet Boek van Kophandel in life insurance by Hoge Raad was interpreted by equal obligation for the insurer to investigate (mededelingsplicht) material facts including the insured's medical records during the process of contract negotiation. As the result, both parties -the insurer and the insured- of life insurance must have accuracy in making contract (contractuele zorgvuldigheid) and honor in contract (contractuele rechtwaardigheid).

The enactment of the Article 251 Wet Boek van Kophandel by the legislator was still less in providing the sense of fairness to all contracting parties. Hence, the enactmen of the Article 31 act (2) the Law Number 40, in 2014 on Insurance which assigned a unilateral obligation toward insurance agencies, insurance brokers, and insurance companies had to provide correct information, with no fake, and/or misleading facts toward the policy holder,

Sprakelijkehidrecht, Juridish up to date, 23/24, 18 December, p. 20-21.

22 P.L.Wery and M.M. Mendel. (2010). Hoofzaken verzekeringsrecht. Martinus: Matthijs Mendel, p. 2021. 
the insured, and participant dealing with the risk, benefits, obligation, and charges related to the conventional or shariah insurance products offered. However, in the Article 31 , act (2) this insurance law did not provide any equal protection guarantee dealing with pre-contract good faith toward the parties. The insurer's obligation to investigate any material facts related to the medical records the insured had informed did not explicitly set in that article. Thus, the legal norms of good faith in the Article 251 Wet Boek van Kophandel and the Article 31 act (2) on insurance law had to be interpreted by judges whenever a dispute between parties emerged.

\section{Court Attitude for the Implementation of Good Faith in Life Insurance Contract}

The obligation to have a good faith in a life insurance contract was implemented under the verdict number $1093 \mathrm{~K} / \mathrm{Pdt} /$ 2010 between Drs. Kusno Widayat and the insurance company he took for his insurance. This verdict of Supreme Court objected the insurance company's cassation. The legal consideration of the court stated that High Court which corroborates District Court did not do any fault in implementing the law. District Court was right in terms of their legal consideration by mentioning that the insurer, on which signing the insurance policy, had to investigate the validity of the insured's data through an investigator team and insurance expert, particularly if the insured's breast had already been lifted. By signing the policy, the insurer admitted or confirmed the validity of the insured's informed data.
Establishing that verdict, The Supreme Court asserted the insurer's obligation to investigate all informed material facts by the insured in SPAJ and SKK before dealing the contract. along with the policy Number 0011560799 on $18^{\text {th }}$ December, 2007, the legal relationship between both parties was finally established as well. The judge of the Supreme Court protected the prudent insured. The insured, as a prudent party, had completed his/her obligation by informing any material facts he/she knew to the insurer in SPAJ and SKK, therefore, the prudent insurer had to investigate those facts through an investigator team and an insurance expert. By signing the contract, the insurer admitted the validity of the data mentioned on SPAJ and SKK. Thus, after the insured died, his/ her beneficiary had rights to accept the benefit value up to $\operatorname{Rp} 210,000,000.00$ (Two hundred and ten million rupiah).

Following that verdict, the judge had implemented the principle of pre-contract good faith, since he/she had considered the rights and obligation of both parties the insurer and the insured- within a dealt contract of life insurance. It was mentioned in the policy Number GH-001560799. Furthermore, Reciprocal duty was common in a life insurance contract. It was particularly known as the principle of proportionality, that reciprocal rights and obligations should be fair and the law had to protect such fairness -preventing any possible loss the insurer might suffer from due to the insured's carelessness- for both parties. Furthermore, the judge broke through the laws by not grammatically interpreting the Article 251 Wet Boek van Kophandel, but, instead, 
used a historical interpretation which the insurer could not stand behind that article for unilaterally abrogating a life insurance contract.

In a case of Eva Hernita vs. PT. Asuransi Jiwa Sequis Life, Number 1949 K/ Pdt/2012, the Supreme Court implemented the principle of pre-contract good faith in their life insurance contract. The verdict of the Supreme Court Number 1949K/Pdt/2012 objected the company's cassation. It was due to the consideration of the Supreme Court that the District Court and the High Court did not misinterpret the law; the reason behind such cassation to object a claim reimbursement could not be accepted and tended to be trumped up of stalling from the responsibility of reimbursement. Moreover, the insurance policy could never be terminated by the insurer until the insured died, thus, it should be valid and prevailed and stick both parties.

In that case, the judge strongly implemented the provision of the Article 1338, act (1) and (3) Burgelijke wet Boek, stating that the contract established between two parties was considered as a rule for both parties and should be implemented with a good faith. The judge argued that as long as the insurer did not terminate the contract, it would keep valid along with all the rights and obligation within. If the insurer felt doubt with the informed information, they should have asked for the contract to be terminated before the insured died.

Following that case, it could be seen that the insured had a good faith to complete SPAJ and SKK the insurer asked for. However, the insurer never investigated the truth of the informed material facts mentioned in SPAJ and SKK, hence, any fault by the insurer would be assigned to the insurer. Kiswanto Setiadi's death had nothing to do with the provisional diagnose of impending stroke ischemic attack neither due to any other disease. It was solely a sudden unexpected nocturnal death that happened while he was sleeping and was later found died in the next morning.

In this case, the judge did not consider the provision of the Article 251 Wet Boek van Kophandel in terms of which part the good faith should prevailed. The judge merely considered that a contract termination could only be done by requesting such issue to the court (nietigbaar) -not by nietig /voidwhich became the underlying reason for the insurer to object the insured's claim. Here, the judge used a systematical and historical interpretation toward the Article 251 Wet Boek van Kophandel in order to provide a sense of fairness to a life insurance contract.

The implementation of pre-contract good faith was seen in a life insurance between Herni Sinurat vs. PT. Avrist Assurance, Number 560 K/Pdt.Sus/2012. The Supreme Court, in a verdict Number $560 \mathrm{~K} /$ Pdt.Sus/2012 on $24^{\text {th }}$ September 2012, acceded the cassation from Herni Sinurat and abrogated the verdict of Tangerang District Court Number 135/Pdt.Plw.BPSK/2012/ PN.TNG on $10^{\text {th }}$ May 2012. In his legal consideration, the judge of the Supreme Court considered that the life insurance history on behalf of the deceased Mardi Simarmata (the insured). An insurance agent, Maureen Ingrid Gantini, offered a health insurance program to the prospective insured. At first, the plaintiff was not willing to have insurance 
due to some reasons. However, the agent did not give up offering his product. The insured felt pity for that and finally decided to agree with all the conditions including SPPA form stuff, first policy payment, policy selection, and the other stuff which the agent set. Furthermore, the claim of the insured's death was also handled by the agent and that both contracting parties had decided the choice of forum which was the dispute resolution through arbitration Number 092/PCP/BPSK. DKI/XI/2011 on $8^{\text {th }}$ November2011, thus, this case would be the authority of BPSK.

In his resolution, the judge of the Supreme Court had examined the verdict from BPSK which was considered proper. The agent who filled SPPA with impropriate facts was considered having bad faith. Furthermore, the plaintiff was considered as one with bad faith as well, since the agent did all those stuff under his authority. It indicated that the insured -the plaintiff- did not provide the true material facts and it posited that the insured did not do his obligation which indicating that he broke the contract.

The Supreme Court asserted that the agent, Maureen Inggrid Gantini, had no good faith since she provided impropriate material facts on SPPA on behalf of the insured's authority. The agent on concerned that the prospective insured would cover the insurance without considering any possible risks might happen. Thus, the verdict of BPSK stating that the good faith relied on the insured and all the insured's rights needed to be legally protected was considered proper.

As the agent took the insured's authority, the insurer had to be responsible with the agent's deceitfulness; hence, the insurer must pay 50 million rupiah to the insured. This provision was set in the Article 28 act (7) mentioning that insurance companies must be responsible with any possible claim reimbursements for their agents did not cede the premium they had received toward the insured. ${ }^{23}$

In that case, the insurer had a responsibility to investigate any material facts they needed to know. Following the reciprocal duty, the insured was responsible to provide any related material facts dealing with his/ her medical records, and the insurer had an obligation to check the validity of those facts. Moreover, the insured's rights should be protected as he/she had a good faith by completing his/her responsibility. The agent who looked after the interests of the insurer had no good faith, resulting in paying the benefit values to the insured.

A good-faith implementation issue in a credit contract requiring a life insurance contract was found in the case of Erna Dwiningsih v. PT. Bank Bumi Putra, Tbk as the defendant I and PT. Asuransi Jiwa Central Asia Raya as the defendant II, Number $424 \mathrm{~K} / \mathrm{Pdt} / 2012$. Under the verdict Number $424 \mathrm{~K} / \mathrm{Pdt} / 2012$ on $26^{\text {th }}$ September 2012, the Supreme Court acceded the request from: I PT.Bank Bumi Putra Tbk ; II. PT.Asuransi Jiwa Central Asia Raya and objected the verdict established by Balikpapan District Court Number 35/Pdt.G/2008/PN.Bpp.on $24^{\text {th }}$ September 2008. In his resolution, the Supreme Court had considered that the insured had provided impropriate facts in dur-

23 Mokhamad Khoirul Huda, Ninis Nugraheni and Kamarudin. (2016). "The Nature of the Contract of Life Insurance Agency after Enactment of the Act Number 40 of 2014 on Insurance". Journal of Advanced Research in Law and Economics. 7(5): 1037-1041. 
ing the court session. The insured posited that during 7 months or two years before fulfilling the contract form, the plaintiff's husband was found suffering from Buli-Buli tumor at the final stadium (a urinary tract tumor). In this case, the plaintiff's husband had been dishonest as mentioned under the provision of the Article 1328 on Civil code, or making deception as mentioned under the provision of the Article 251 on Wet Boek van Kophandel.

The agreement to close credit between the plaintiff's husband and the defendant II was not legally valid, hence, the defendant's attitude that objected the termination of the plaintiff husband's liability on the defendant I was considered legally reasonable. In his resolution, the Supreme Court had implemented the pre-contract good faith with a subjective standard in which from the beginning, the insurance contract was considered abolished by the law, since deception was assumed within.

The insured was assigned to provide any related material facts informing his medical records, and the insurer had a responsibility to investigate those all facts. Judge's consideration on the Supreme Court did not rely on a reciprocity duty or proportionality. The judge merely interpreted the provision of the Article 251 on Wet Boek van Kophandel in grammatical manner, hence, it did not reflect the sense of fairness for the insured. Before the insurance to be covered, the insured had conducted a medical check-up in Khatulistiwa Labs on $6^{\text {th }}$ January 2007 which result was mentioned in laboratory document Number 112520 submitted to the insured. The insured had completed SPPAJK form in accordance to the insurance terms of condition. In this case, the insured should be considered as the prudent party which rights should be protected. It might be unfair if the fault that defendant I and defendant II had done was assigned to the insured.

Similarly, Wirjono Projodikoro argued that a subjective good faith was a good faith presented from the beginning since a legal relationship was established. It was commonly in the form of a supposition that both parties should meet all the necessary terms of conditions for establishing a legal relationship. However, if one of those conditions was, in fact, not met, the prudent party should not be aggrieved.

In that verdict, the judge's consideration on the Supreme Court did not show what the real essence of a good faith is and how the obligations of the two parties -the insured and the insurer- would be in relation with material facts. The judge did not deeply examine the provision of the Article 251 on Wet Boek van Kophandel. It was found by his resolution for the life insurance to be terminated on behalf of the law. Given that the norm under the Article 251 on Law of Business Code could go by the board due to a will defect, particularly because of error/ fallacy in relation with the subjective conditions mentioned in the Article 1320 on Burgelijke wet Boek.

\section{CONCLUSION}

The interpretation of pre-contract good faith had a subjective standard based on honesty to thoroughly inform any related material facts dealing with the object of an insurance. Parties, in establishing a contract, 
should be prudent to investigate of check any material facts related to the object of the contract, from the way of negotiating up to implementing the contract. Therefore, in a pre-contract good faith, each party must be prudent (contractuele zorgvuldigheid) and honorable for the contract (contractuele rechtwaardigheid). The negotiation of a life insurance contract should be based on a good faith of both parties, besides the principles of proportionality in order to reach the sense of fairness for each party.

Until recent days, Indonesia Court did not have a full interpretation of pre-contract good faith in terms of life insurance contract, and it resulted in its inconsistent implementation with confusing parameter on the verdict. In order to bring out a shared interpretation and a good-faith standard on pre-contract of life insurance, the Supreme Court should provide a guidance of pre-contract good faith for life insurance contract in the form of SEMA (Surat Edaran Mahkamah Agung/ Supreme Court Circular) which got the insured to inform any material facts (mededeling plicht) and got the insurer to investigate those all material facts (onderzoekplicht).

\section{BIBLIOGRAPHY}

Anonymous. "Dana Pertanggungan Asuransi Jiwa Capai Rp.1.946 Triliun.” Available at: http://www.e-Money News. htm, [Acessed on May 1, 2015].

Badan Pusat Statistik. (2011). Statistik Indonesia (Statistical Yearsbook of Indonesia 2011). Jakarta: BPS.

Badan Pusat Statistik. (2015) Statistik Indonesia (Statistical Yearsbook of Indonesia 2015). Jakarta: BPS.
Benjamin N. Cordozo. (2009). The Nature of The Judicial Process. New York: Cosimo. Inc.

BMAI."Rekapitulasi Jumlah Sengketa." Available online at: http://www.bmai. or.id/ [Accessed on 18 April 2014].

Carlo van Eijken, Bestaan er Verschillen Tussen het Nederlandse en het Engelse Recht als het Gaat om de Goede Trouw Tijdens de Onderhandelingen bij Bedrijfsovernames?, Scriptie Geschreven ter Afronding van de Master Privaatrechtelijke Rechtspraktijk aan de Universiteit van Amsterdam.

Douglas F. Robinson Q.C. and John Neocleous. (1998). "Issues of Insurance Fraud". International Symposium on The Prevention \& Control of Financial Fraud, Beijing, 19-22, October 1998.

Harifin A. Tumpa. (2015). "Penerapan Konsep Rechtsvinding dan Rechtsschepping oleh Hakim dalam Memutus Suatu Perkara". Hasanuddin Law Review, 1(2), 126-138. doi: http://dx.doi. org/10.20956/halrev.v1n2.90

H.M.N. Purwosutjipto. (1990). Pengertian Pokok Hukum Dagang Indonesia: Hukum Pertanggungan. Jakarta: Djambatan.

Irene Kull. (2002). "Principle of Good Faith and Constitutional Values in Contract Law". Juridica International, VII: 142-148.

M. Keijzer de Korver. (2008). Verzekering en aan Sprakelijkehidrecht, Juridish up to date, 23/24, 18 December, p. 2021.

Man Suparman and Endang. (2004). Hukum Asuransi: Perlindungan Tertanggung, 
Asuransi Deposito, Usaha Perasuransian. $3^{\text {rd }}$ edition. Bandung: Alumni.

Mokhamad Khoirul Huda. (2016). Prinsip Iktikad Baik dalam Perjanjian Asuransi Jiwa. Yogyakarta: UII Press.

Mokhamad Khoirul Huda, Ninis Nugraheni and Kamarudin. (2016). "The Nature of the Contract of Life Insurance Agency after Enactment of the Act Number 40 of 2014 on Insurance". Journal of Advanced Research in Law and Economics. 7(5): 1037-1041.

P.L.Wery and M.M. Mendel. (2010). Hoofzaken verzekeringsrecht. Martinus:
Matthijs Mendel.

Ridwan Khairandy. (2004). Iktikad Baik dalam Kebebasan Berkontrak. Jakarta: Universitas Indonesia.

Robert Merkin. (2007). Practical Insurance Guides: Insurance Law-An Introduction. London: Informa.

Santoso Poedjosoebroto. (1969). Beberapa Aspek tentang Hukum Pertanggungan Jiwa di Indonesia. Jakarta: Bhratara.

Viktor Dover. (1975). A Handbook to Marine Insurance. $8^{\text {th }}$ edition. London: Withherby \& Co. Ltd. 